\title{
PELATIHAN SERVICE RUTIN KENDARAAN BERMOTOR UNTUK PERKUMPULAN OJEK MERJOSARI KECAMATAN LOWOKWARU KOTA MALANG
}

\section{Aladin Eko Purkuncoro ${ }^{1 *}$, Anang Subardi²}

Teknik Mesin

Institut Teknologi Nasional Malang

1aladin.eko.purkuncoro@lecturer.itn.ac.id

ªnang_subardi@fti.itn.ac.id

* Corresponding author

\begin{abstract}
ABSTRAK
Dengan penerapan pembelajaran service yang dikembangkan ini diharapkan bisa membantu tukang ojek dalam menjalankan usahanya secara baik dan menguntungkan. Demikian pula dari segi ekonomi diharapkan membawa dampak pada peningkatan penghasilan sebagai konsekuensi. Dengan demikian maka secara tidak langsung ikut mendorong pertumbuhan ekonomi dan pembangunan secara nasional. Pasaran tukang ojek selama ini berjalan sangat baik karena tukang ojek sangat digemari oleh masayarakat baik lokal maupun wisatawan. Usaha ini cukup potensial karena tukang ojek dapat memperoleh hasil dengan harga cukup tinggi berkisar dari Rp 40.000, sampai dengan Rp 50.000, - per hari. Keuntungan yang diperoleh selama ini meskipun tidak tinggi tetapi cukup memadai, selain untuk biaya kebutuhan sehari-hari juga untuk kelanjutan perkembangan usaha ini dari hari ke hari.
\end{abstract}

KATA KUNCI: Pelatihan, service, otomotif. kalangan masyarakat, maka usaha pangkalan ojek ini mempunyai prospek yang baik dan menguntungkan.

Usaha ojek merupakan salah satu usaha yang paling populer di daerah Merjosari. Hal ini dikarenakan di daerah tersebut terdapat sebuah taman yang cukup ramai di kota Malang. Dengan kondisi inilah, maka mereka memutuskan untuk berprofesi sebagai tukang ojek. Pendapatan yang dihasilkan pun cukup untuk memenuhi kebutuhan mereka.

Kendala utama yang dihadapai oleh mitra adalah selain modal yang terbatas, mereka juga tidak memiliki kemampuan untuk memperbaiki atau service sepeda motor. Proses pembelajaran service pada tukang ojek dilakukan secara bergiliran, dengan memberikan materi service ringan pada sepeda motor. Kendala ini menyebabkan pengeluaran biaya memperbaiki sepeda motor. vang dimiliki cukup baik karena sejauh ini pangkalan ojek selalu ramai. Peluang yang dimiliki pun sangat bagus karena selain sangat digemari oleh masyarakat, ojek sendiri cukup cepat mengantar penumpang dan biayanya sangat terjangkau di dapat berjalan lancar, sehingga omzet dapat bertambah dengan kualitas transportasi dan harga dapat bersaing di transportasi yang lain.

Saat ini usaha ojek yang berada di kawasan Taman Merjosari yang berpusat di kawasan Lowokwaru Kota Malang sedang berusaha untuk mengoptimalkan sumber daya yang dimiliki mengingat persaingan semakin ketat. Potensi taman

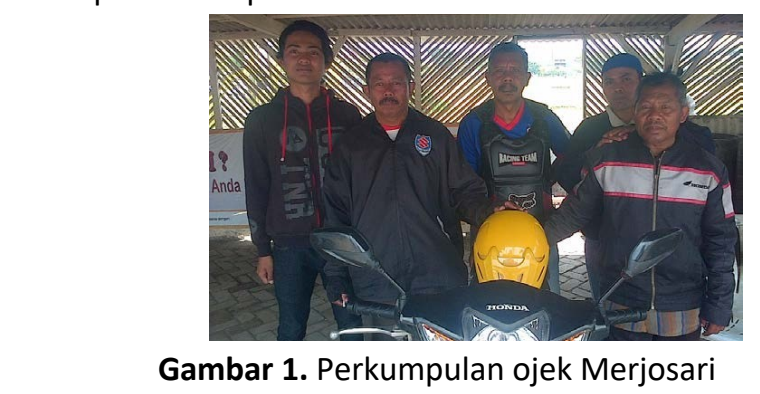

Gambar 1. Perkumpulan ojek Merjosari

Adapun tujuan dari pelatihan service motor, antara lain adalah sebagai berikut :

1. Memperkenalkan kepada mitra untuk 
mengenalkan teknologi otomotif terutama dalam hal teknologi untuk proses service pada sepeda motor melalui pembelajaran peralatan yang lebih maju

2. Menerpakan service sepeda motor yang lebih efektif dan efisien sehingga diharapkan dapat meningkatkan kemampuan tukang ojek.

3. Dengan menerpakan service sepeda motor yang diberikan ini diharapkan dapat mendukung dan meningkatkan kemampuan tukang ojek sekaligus dapat meningkatkan pendapatan industri tukang ojek.

4. Sebagai wujud nyata partisipasi dunia pendidikan dalam pengabdian kepada masyarakat.

Kegiatan ini bersifat pendidikan dan pelatihan serta perbaikan sarana penunjang usaha dengan aplikasi usaha untuk membantu tukang ojek dalam menjalankan usahanya sehingga diharapkan usaha ini dapat lebih berkembang dan dapat memberikan keuntungan yang memadai. Evaluasi kegiatan akan dilakukan setelah pelatihan service sepeda motor di tempat mitra. Pelatihan aplikasi usaha meliputi bagaimana mengoperasikan service sepeda motor, teknik pelatihan, dan teknik perbaikan sepeda motor.

Pelatihan materi service sepeda motor yang dikembangkan dalam kegiatan pelatihan service pada tukang ojek dengan memberikan materi-materi dan tata cara memperbaiki sepeda moto r. Dibandingkan dengan cara service di bengkel yang membutuhkan biaya untuk memperbaiki kerusakan pada sepeda motor.

\section{BAHAN DAN METODE}

1. Melakukan wawancara kepada usaha ojek yang berada di kawasan taman merjosari yang berpusat di kawasan Lowokwaru kota Malang, kepala Kelurahan dan masyarakat.

2. Melakukan pengamatan aktivitas dengan jalan mendokumentasikan kegiatan masyarakat dalam bentuk foto dan pengumpulan data proses kerja.

3. Pelatihan service sepeda motor kepada pengemudi ojek.

4. Pelaksanaan pengabdian masyarakat mulai dai survey, study literature sampai pembuatan beberapa produk dari bahan lain untuk lebih mempunyai pengalaman dalam proses pembuatan bahan produk seperti diagram alir proses pengabdian (dapat dilihat pada gambar 1).

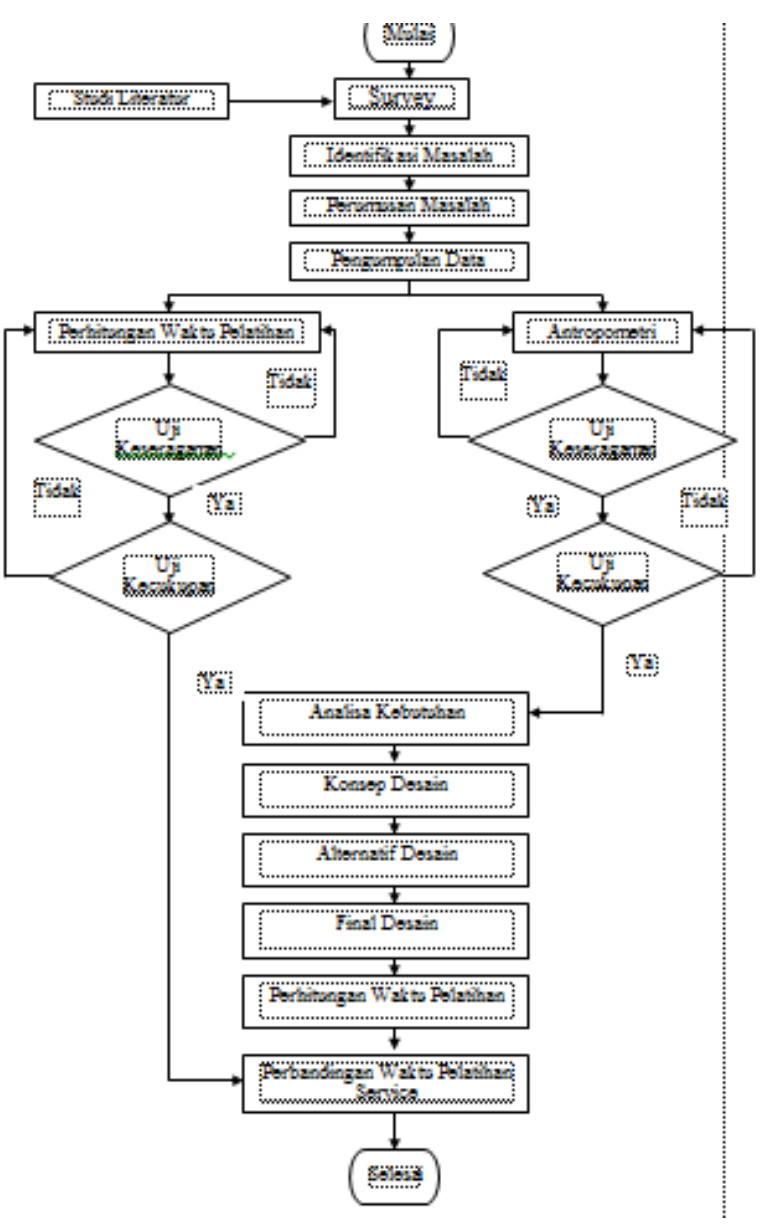

Gambar 2. Diagram Alir Proses Pengabdian

\section{HASIL DAN PEMBAHASAN}

'Metode yang akan diterapkan terdiri dari pembuatan beberapa jobsheet produk komposit hybrid dan paltihan cara dan penggunaan, serta pembuatan produk dengan proses pengelasan yang diharapkan dapat menghasilkan sebuah produk berkualitas. Pelaksanaan pengabdian masyarakat ini dimulai dari survei, study literatur sampai pembuatan beberapa produk dari bahan lain dalam rangka memperluas wawasan dalam proses pembuatan produk.

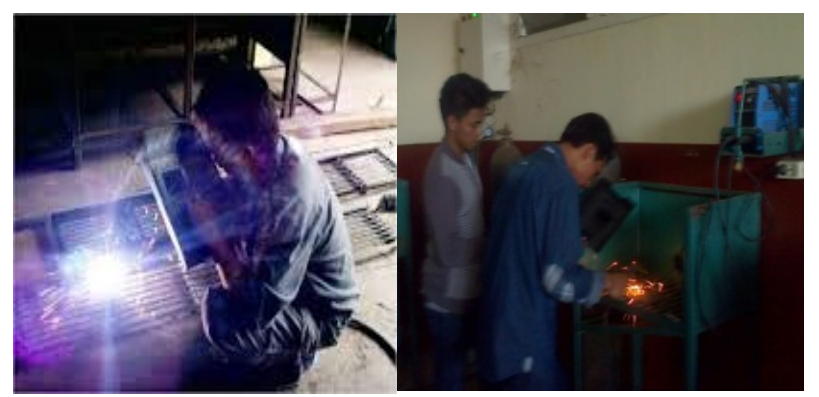

Gambar 3. Pelatihan perbaikan di bengkel 
Bagi Kampus Institut Teknologi Nasional Malang kegiatan ini merupakan wujud nyata partisipasi dunia pendidikan dalam pengabdian kepada masyarakat melalui pendidikan dan pelatihan maupun penerapan teknologi otomotif sehingga masyarakat dapat memanfaatkannya dalam menjalankan usahanya. Dengan mengembangkan pembelajaran dan pelatihan otomotif dapat menunjang usaha tukang ojek.

Selain itu secara tidak langsung membantu pemerintah daerah dalam hal ini dinas terkait (Dinas Nakertrans) untuk memberikan pendidikan dan pelatihan kepada masyarakat terutama pendidikan non formal di bidang keterampilan sehingga terjadi peningkatan kualitas sumberdaya manusia. Dengan demikian diharapkan masyarakat mampu meningkatkan kemampuan sehingga usaha ini dapat berkembang menjadi usaha yang produktif dan menguntungkan.

\section{KESIMPULAN DAN SARAN}

\section{Kesimpulan}

Dari hasil pengamatan selama pelaksanaan pelatihan kemudian mengevaluasinya maka pelaksanaan Pelatihan aplikasi usaha meliputi bagaimana mengoperasikan service sepeda motor, teknik pelatihan, teknik perbaikan sepeda motor, ini dapat disimpulkan bahwa:

1 Kegiatan Pelatihan aplikasi usaha meliputi bagaimana mengoperasikan service sepeda motor, teknik pelatihan, teknik perbaikan sepeda motor ini terselenggara berkat kerjasama dengan Lab. Otomotif Teknik Mesin ITN Malang sebagai pelaksana. Pelatihan ini merupakan pemberian bekal pengetahuan dan ketrampilan agar UKM Ojek POPMI pengembangan peralatan teknologi otomotif untuk memanfaatkan ilmu pengetahuan tentang otomotif dan service agar tukang ojek dapat memperbaiki sendiri kerusakan pada sepeda motornya

2 Dengan penerapan pembelajaran service yang dikembangkan ini diharapkan bisa membantu tukang ojek dalam menjalankan usahanya secara baik dan menguntungkan. Demikian pula dari segi ekonomi diharapkan membawa dampak pada peningkatan penghasilan sebagai konsekuensi. Dengan demikian maka secara tidak langsung ikut mendorong pertumbuhan ekonomi dan pembangunan secara nasional.

\section{Saran}

Dari hasil pengamatan selama pelaksanaan usaha ojek yang berada di kawasan pasar dinoyo yang berpusat di kawasan Lowokwru Kabupaten Malang, maka karni berupaya untuk menyarankan kepada ITN Malang melalui LP2M ITN Malang bahwa:

1 Perlu mengadakan suatu kegiatan penyuluhan kewirausahaan perbengkelan perawatan sepeda motor ojek POPMI Malang.

2 LP2M ITN Malang sangat pertu mengadakan suatu hubungan yang lebih luas ke lembaga pemerintahan guna dapat melaksanakan program-program pelatihan yang sejenis.

\section{PERSANTUNAN}

Ucapan terima kasih kepada LPPM Institut Teknologi Nasional Malang yang sudah mensupport pelaksanaan pengabdian kepada masyarakat. Terima kasih juga kepada para anggota yang telah melaksanakan tugas dengan penuh tanggungjawabn.

\section{DAFTAR PUSTAKA}

[1] Drs. Daryanto; Teknik Merawat Otomotif, Bandung. 2002.

[2] PT. Astra PT. Astra International; Technical Service Training, Jarakta, 2004

[3] Joseph E Shigley, Larry D Mitchell, Gandhi Harahap. 1994 : Perencanaan TeknikMesin. Erlangga. Jakarta

[4] Sularso, Kiyokatsu Suga. 1997 : Dasar Perencanaan Dan Pemilihan Elemen Mesin. Pradya Paramita. Jakarta

[5] Serope Kalpakjian; 1985, Manufacturing Processes for Engineering Materials, Addison-Wesley Publishing Company, California. 